\title{
1. Intellectual property law in China - from legal transplant to governance
}

\section{Nari Lee}

\section{INTRODUCTION}

Intellectual property (IP) law aims to foster innovation and creativity in a society by granting private rights excluding others from using information defined as the object of such rights. Due to the role they play in generating added value in international trade, IP laws are increasingly made and influenced by international norms imposed by conditions set in international agreements, such as the TRIPs Agreement. ${ }^{1}$ More and more, governments are seen to be actively using the rhetoric of intellectual property rights (IPR) as an instrument of innovation and cultural policy to improve national competitiveness in the global economy. ${ }^{2}$ Due to the importance of IPR and the added value they generate, innovation seems to take a central place in national economic policy in Asia and Europe alike. ${ }^{3}$

The economic importance of IP invites a form of norm competition, as different norms, laws and standards on the protection and uses of IP compete with each other internationally - which is sometimes referred to as IP arbitrage. ${ }^{4}$ The norm competition is made clearly visible in the

1 Agreement on Trade-Related Aspects of Intellectual Property Rights, 15 April 1994, 33 ILM 81 (hereinafter TRIPs Agreement).

2 For example, the EU IP Strategy 2011: European Commission, Communication from the Commission to the European Parliament, the Council, the European Economic and Social Committee and the Committee of the Regions. A Single Market for Intellectual Property Rights. Boosting Creativity and Innovation to Provide Economic Growth, High Quality Jobs and First Class Products and Services in Europe (Brussels, 24 May 2011, COM (2011) 287 final).

3 See, for example, Liguo Zhang, 'Recent IP Legal Reforms in China and the EU in light of Implementing IPR Strategies', Chapter 10 in this volume.

4 P. Samuelson, 'Intellectual Property Arbitrage: How Foreign Rules Can Affect Domestic Protections' (2004) 71 University of Chicago Law Review 223-239. 
context of new international trade treaty negotiations in various forums. ${ }^{5}$ As these regulatory competitions show, the nature and foundation of IP law still remain contested, despite the acceptance of IPR as a pragmatic instrument to further the economic growth of a nation. Notably, the discussion on the origin of modern IP law may be one topic that rehashes the differences on the foundation of IP. Modern IP law is often pictured and presented to be an invention as well as an outcome of historical evolution and deliberate interventions by political authorities in the legal tradition of a certain nation or 'the West', despite the attempt to show the contingency of the current IPR institutions with property rights over mental objects. ${ }^{6}$

As seen in the discussions of traditional knowledge and expression, framing traditional knowledge in the context of a private property right has caused controversies. ${ }^{7}$ Even in less contentious subject matters, the expanding boundary of IP highlights the inherent tension between nations with heterogeneous economic interests and traditions.

Such conflicts and tension raised during the process of IP law harmonization present serious concerns. Fundamentally, the question is about the origin of IP norms and the genealogy of law and whether they matter in efficient implementation of IP laws. Law reforms even within Europe, from where modern IP law is said to originate, are not entirely without controversy. Indeed, convergence of norms in European harmonization projects has had its share of critics. ${ }^{8}$ Notably, in an essay published in 1996,

5 See, for example, Peter K. Yu, 'TPP and Trans-Pacific Perplexities' (2013) 37 Fordham Int'1 LJ 1129, showing how some regions are excluded from the treaties, to include some trade terms that were rejected by them earlier. See also, what Dinwoodie and Dreyfuss described as regulatory competition in G. Dinwoodie and R.C. Dreyfuss, 'Designing a Global Intellectual Property System Responsive to Change: The WTO, WIPO, and Beyond' (2009) 46 Houston Law Review 1187.

6 See generally, Brad Sherman and Lionel Bently, The Making of Modern Intellectual Property Law: The British Experience, 1760-1911 (Cambridge University Press 1999). However, they highlight the contingent nature of the law, which resulted from a 'complex and changing set of circumstances' at 6.

7 In the context of traditional cultural expression and traditional knowledge and patent claims, Gunther Teubner and Andreas Fischer-Lescano, 'Cannibalizing Epistemes: Will Modern Law Protect Traditional Cultural Expressions?' in Christoph Graber and Mira Burri-Nenova (eds), Traditional Cultural Expressions in a Digital Environment (Edward Elgar Publishing 2008).

8 G. Teubner, 'Legal Irritants: Good Faith in British Law or How Unifying Law Ends Up in New Differences' (1998) 6 Modern Law Review 111-132; W. Van Gerven, 'Comparative Law in a Texture of Communitarization of National Laws and Europeanization of Community Law' in D. O'Keeffe and A. Bavasso (eds), Judicial Review In European Union Law - Liber Amicorum in Honour of Lord Slynn of Hadley 1 (Kluwer Law International 2000) 433. 
Legrand observed that all efforts at convergence actually failed to produce a harmonized system of European law, based on the fundamental differences in legal culture and legal systems in Europe. ${ }^{9}$ The observation is still relevant in the implementation of EU IP laws and ongoing initiatives of the EU IP law unification agenda. ${ }^{10}$ Arguably, the problem of origin may not be as great a concern as for a country where the norms are transplanted. It would be more difficult, for example, to raise a culturally relativist claim in the implementation of IP laws in a European Member State, such as those made by Alford on Chinese copyright law, that IP infringement may be somewhat culturally justifiable. ${ }^{11}$ A common understanding that 'intellectual property shall be protected' 12 seems to exist in Europe and there is some common rationality for an individual private property right as well as the belief that creations of mind and abstract objects may be protected, regardless of justification - natural right or utilitarian rationality.

In contrast, various nations in Asia, by design as well as by force, have received laws and systems of laws from Europe. For example, foreign laws and legal systems' influence on modern Japanese law has been well documented. ${ }^{13}$ In particular, transplantation of the European law into the Japanese system has even generally been viewed as positive and successfully integrated in the local social order. ${ }^{14}$ In contrast, the introduction

9 Pierre Legrand, 'European Legal Systems Are Not Converging' (1996) 45(1) International and Comparative Law Quarterly 52-81.

10 See, for example, on the problems of Europeanization of IP right, Justine Pila. 'The European Patent: An Old and Vexing Problem' (2013) 62(4) International and Comparative Law Quarterly 917-940; B. Hugenholtz, 'Why the Copyright Directive Is Unimportant, and Possibly Invalid' (2000) 22(11) European Intellectual Property Review 499-505; L.R. Helfer, 'The New Innovation Frontier? Intellectual Property and the European Court of Human Rights' (2008) 49 Harvard International Law Journal 1. See also for an overview, J. Pila and A. Ohly (eds), The Europeanization of Intellectual Property Law: Towards a European Legal Methodology (Oxford University Press 2014).

11 William P. Alford, To Steal a Book Is an Elegant Offense: Intellectual Property Law in Chinese Civilization (Stanford University Press 1995).

12 See, however, C. Geiger, 'Intellectual Property Shall be Protected!? Article 17(2) of the Charter of Fundamental Rights of the European Union: a Mysterious Provision with an Unclear Scope' (2009) 31(3) European Intellectual Property Review 113-117.

13 See, for example, Hiroshi Oda, Japanese Law (Oxford University Press 2009). On the European influence on Japanese civil law, see, for example, Zentaro Kitagawa and Karl Riesenhuber (eds), The Identity of German and Japanese Civil Law in Comparative Perspectives/Die Identität des deutschen und des japanischen Zivilrechts in vergleichender Betrachtung (De Gruyter 2007).

14 Oda (supra, n 13), who argues that despite the mystifying argument of disparity between local norms and transplanted law, foreign laws were received by 
of the Western system of laws into China and Korea coincides with the marred history of colonialism as well as Japanese imperialism and thus such success is rarely claimed..$^{15}$ As such, predominance of narratives of the legal transplant in the discussion of Asian IP law may seem a logical extension of the debates on the origin of the modern legal system and the rule of law in Asia. ${ }^{16}$

The introduction of modern IP law to China provides one example of legal transplant of a system which originates from Europe, documenting a process of adaptation and rejection of transplanted systems and norms across cultures. ${ }^{17}$ This chapter argues that the perspective of governance needs to be added to the comparative study of Chinese and European IP law. If legal transplant is a narrative to explain the first wave of normative changes in Chinese IP law and IP law reforms, often resulting from foreign forces and external pressures, this chapter argues that a perspective of governance may better explain the second wave of normative changes in Chinese IP law.

\section{NARRATIVE OF LEGAL TRANSPLANT APPLIED TO CHINESE IP LAW}

\subsection{Legal Transplant as a Narrative}

Legal transplant as a theory in comparative law to explain norm and systemic interactions in laws, across different cultures, is not without

Japan without much resistance, as the need for modernization was locally felt. He also highlighted the fact that absence of colonial rulers imposing foreign rule has made the reception smoother as there was broader political support for its reception. Additionally, selective reception as witnessed by the Civil Code, which is a concoction of German, French and English law, has also smoothed the process. Finally, as the transplanted laws were modified to suit the existing customs and conventions, including commercial practices, he considered Japanese legal transplant to be successful.

15 See Alford (supra, n 11) at 30-55, where he describes it as 'learning the law at gunpoint'.

${ }_{16}$ See also, Deming Liu, 'The Transplant Effect of the Chinese Patent Law' (2006) 5(3) Chinese Journal of International Law 733-752.

17 See Peter $\mathrm{Yu}$, 'The transplant and transformation of intellectual property laws in China', Chapter 2 in this volume. See also Paul Edward Geller, 'Legal Transplants in International Copyright: Some Problems of Method' (1995) 13 UCLA Pacific Basin Law Journal 199; Wei Shi, 'Globalization and Indigenization: Legal Transplant of a Universal TRIPS Regime in a Multicultural World' (2010) 47(3) American Business Law Journal 455-507. 
controversy. Various comparative lawyers have assessed and identified negative and positive aspects of borrowing or transplanting legal concepts and systems into a different cultural context. ${ }^{18}$ Starting from the very notion of law rooted in the soil of the nature, some have been more negative about the idea, ${ }^{19}$ while others seem more positive, leaving room for such legislative experimentation. ${ }^{20}$ Notably, if the law is there to recognize a pre-existing normative order, without localization, the laws that are introduced to a foreign culture may only be implemented successfully as a matter of an 'unusual and accidental coincidence' as noted by Montesquieu. ${ }^{21}$ If the origin of the law is so important in the implementation of the legal norms, then the system of IP based on IP laws with foreign norms would likely fail. Or, as believed by Watson, laws may be autonomous and as such be transplanted, ${ }^{22}$ while the correctness of the metaphor of legal transplantation may be questioned. ${ }^{23}$ Some may question the behavioural dynamics induced by the transplanted law, ${ }^{24}$ and while some may question the very possibility of comparison, at least among those that accept such possibilities of comparison, the necessity to adapt or modify the transplanted systems to local conditions are highlighted. ${ }^{25}$ Taking his cue from Watson, Mattei, for example, highlighted economic efficiency

18 See for a cogent summary of the history of the theory, John W. Cairns, 'Watson, Walton, and the History of Legal Transplants' (2012) 41 Georgia Journal of International \& Comparative Law 637.

19 See, for example, F.K. von Savigny, Vom Beruf unserer Zeit für Gesetzgebung und Rechtswissenschaft [Of the Vocation of our Age for Legislation and Jurisprudence] (Abraham Hayward tr, first published 1814, The Law Book Exchange 2002).

20 See among others, A. Watson, Legal Transplants: An Approach to Comparative Law (University of Georgia Press 1974). See also A. Watson, 'Legal Transplants and European Private Law' (2000) 4.4 Electronic Journal of Comparative Law, <http://www.ejcl.org/44/art44-2.html> accessed 10 December 2014.

21 Charles de Secondat, Baron de La Brède et de Montesquieu, The Spirit of Laws (1748) Book. I, ch. 3, para. [12]. He notably argued that 'que c'est un grand hazard si celles d'une nation peuvent convenir à une autre' ('it is very unlikely for those of one nation to be proper for another'). The English translation is from David Wallace Carrithers (ed), The Spirit of Laws: A Compendium of the First English Edition (University of California Press 1977) at 105.

22 Watson (supra, n 20).

23 Teubner (supra, n 8) has notably used the term 'legal irritants'.

24 Ann W. Seidman and R.B. Seidman, State and Law in the Development Process: Problem Solving and Institutional Change in the Third World (St Martin's Press 1994).

25 K. Zweigert and H. Kötz, Introduction to Comparative Law (Tony Weir tr, 3rd edn, Clarendon Press 1998). 
in legal transplant. ${ }^{26}$ In between the extremes of impossibility and the ease of legal transplant, Kahn-Freund submits that there are degrees of transferability. According to him, the success of a transplant depends on how closely a foreign institution or law is connected with a distribution of power in the foreign country that is not shared in the recipient country, and how it is likely to be received by organized interest groups in its new setting. ${ }^{27}$

Researchers working on the topic of Chinese law are also warned of the possibility that the concept of law may be so different in China that an eager application of so-called functional comparison would lead to an incorrect observation or conclusion. ${ }^{28}$ This warning may very well be worth considering in cases that are so fundamentally local in nature, and where the legal or regulatory arrangement may evolve without particularly using the same rationalities and doctrinal concepts as used and accepted elsewhere. ${ }^{29}$ In contrast, if infrastructural institutions are in place and transplanted and used as a means to emulate new norms, insistence on fundamental differences based on cultural relativism may be misleadingly mystifying.

However, once the mystifying claims for a difference are cleared, there are actual and real problems in using legal transplant as a method to induce changes in a society. As noted by Seidman and Seidman, it is hard to verify the causality of outcome of the changes in a society: 'inevitably, people choose how to behave, not only in response to the law, but also to social, economic, political, physical and subject factors arising in their own countries from custom, geography, history, technology and other non legal circumstances' ${ }^{30}$ The changes may very well have been caused by factors external to law such as power relations, politics, technology and culture. Indeed, the failure of law and development projects that ambitiously asked the question whether law matters in economic development highlight the difficulty of the task of assessing the impact of the law. ${ }^{31}$ As it

26 Ugo Mattei, 'Efficiency in Legal Transplants: An Essay in Comparative Law and Economics' (1994) 14(1) International Review of Law and Economics 3-19.

27 Otto Kahn-Freund, 'On Uses and Misuses of Comparative Law' (1974) 37(1) Modern Law Review 1-27.

28 See, for example, Teemu Ruskola, Legal Orientalism (Harvard University Press 2014) 33-36. Legal realists may likewise challenge the notion of functional comparison of superficial similarities as the substantive legal relations underlying them may well be entirely different.

29 Alf Ross, 'Tû-Tû' (1957) 70 Harvard Law Review 5, 812-825.

30 Seidman and Seidman (supra, n 24) at 45.

31 See, for examples of such criticism, Tom Ginsburg, 'Does Law Matter for Economic Development? Evidence From East Asia' (2000) 34(3) Law \& Society 
is unclear what impacts on behavioural changes should be examined, this also makes it hard to measure the success of transplant. Unlike organic transplant, the measurement of a successful legal transplant of a social construct may be impossible as binary causality is impossible to establish in a complex social system.

\subsection{Legal Transplant of IP Law Norms to China}

When applied to the development of Chinese IP laws, comparative law debates seem to be dominated by more negative than positive narratives of legal transplant. ${ }^{32}$ If one looks only at the reports of challenges to enforcement of IPR, one may well concur with such an observation on the failure of transplantation of alien norms to Chinese soil. ${ }^{33}$ On a closer look, however, it is possible to note that the narrative of legal transplant may provide only a partial explanation of IP norm interactions in China. ${ }^{34}$ IP law reforms in China in recent years seem to be going beyond the local adaptation of the received norms, but are also driven by indigenous demands for new norms to govern and to be governed.

In the area of IP laws alone, various scholars and commentators have argued that it is nearly impossible to say with certainty what impact IP law has on technological, creative or aesthetic progress, as it purports to do. Economists have also convincingly shown that we do not even know whether it is a good idea to try to influence production and use of nonrival and non-excludable knowledge goods with an artificially constructed regime of scarcity - and exclusivity. ${ }^{35}$ As such, trying to measure the

Review 829-856; Kevin Davis and Michael Trebilcock, 'The Relationship between Law and Development: Optimists vs. Sceptics' (2008) 56 American Journal of Comparative Law 895.

32 Alford (supra, n 11). See for an example of criticism, Shi Wei, 'Cultural Perplexity in Intellectual Property: Is Stealing a Book an Elegant Offense?' (2006) 32 North Carolina Journal of International Law and Commercial Regulation 1,11 .

33 For example, United States Trade Representative (USTR), 2015 Special 301 Report (2015) at 33-43 <https://ustr.gov/sites/default/files/2015-Special-301Report-FINAL.pdf> accessed 31 May 2015.

34 See, for example, Yu (supra, n 17) and Benjamin Liu, 'The glocalization of patent linkage in China', Chapter 9 in this volume.

35 Fritz Machlup, An Economic Review of the Patent System: Study of the Subcommittee on Patents, Trademarks, and Copyrights of the Committee on the Judiciary, United States, Senate; Eighty-fifth Congress, Second Session; Pursuant to S. Res. 236 (US Government Printing Office 1958). Fritz Machlup and Edith Penrose 'The Patent Controversy in the Nineteenth Century' (1950) 10(1) Journal of Economic History 1-29. Compare James Bessen and Michael James 
impact of transplanted IP law on the local economy is predetermined to be an unclear project.

Nevertheless, if a society may be ruled by the law, introduction of specific regulations should produce some changes at least observable through changed behaviours of the directly regulated target group. Likewise, the success or failure of a legal transplant may be measured through the changes or the absences in the behaviours, before and after the introduction of the norm. Likewise, it is possible to argue that a transplanted norm may be considered rejected, not only when it is vocally opposed by the locals, but also when it remains as irrelevant dead letters in the law book, not referred to, respected or used in practice. ${ }^{36}$ In contrast, one may argue that the success may be measured if the new norms are accepted and used by the locals efficiently to settle disputes, instead of the alternatives, or to generate more norms (to make more norms) to introduce further changes, ${ }^{37}$ or to otherwise regulate and coordinate conduct of the governed, in the domain regulated by the introduced norm. ${ }^{38}$

Legal transplant highlights origins in the law. In other words, when viewed through the lens of legal transplant, it is the genealogy of a norm, rather than what it regulates, and how it functions in the present tends to become highlighted. Some scholars who study the political economy of the law have pointed out, for example, that the development is a continuation of colonialist history or imperialism, imposed by way of external pressure, ${ }^{39}$ while others have postulated that such legal transplant is based on deliberate local motivation of the recipient country. ${ }^{40}$ In the history of

Meurer, Patent Failure: How Judges, Bureaucrats, and Lawyers Put Innovators at Risk (Princeton University Press 2008).

36 See, for example, Weiguang Wu, 'China's CMC system and its problems from the Copyright Law of 1990 to its third amendment', Chapter 11 in this volume.

37 As documented in Lionel Bently, 'The "Extraordinary Multiplicity" of Intellectual Property Laws in the British Colonies in the Nineteenth Century' (2011) 12 Theoretical Inquiries in Law 161-200.

38 As observed on Chinese copyright businesses in Lucy Montgomery, China's Creative Industries: Copyright, Social Network Markets and the Business of Culture in a Digital Age (Edward Elgar Publishing 2010).

39 See, for example, Alexander Peukert, 'The Colonial Legacy of the International Copyright System' forthcoming in Mamadou Diawara and Ute Röschenthaler (eds), Staging the Immaterial. Rights, Style and Performance in Sub-Saharan Africa (Sean Kingston, forthcoming); A. Samuel Oddi, 'TRIPS Natural Rights and a Polite Form of Economic Imperialism' (1996) 29 Vanderbilt Journal of Transnational Law 415.

40 See Peter K. Yu, 'Intellectual Property, Economic Development, and the China Puzzle' in Daniel J. Gervais (ed), Intellectual Property, Trade and 
colonialism, it is argued that legal transplant of copyright law may have been used as a deliberate and calculated means of governance and may hint at a mentality of governing. ${ }^{41}$

Literature presenting the recipient nation's successful statutory implementation of international treaty obligations as evidence of a successful legal transplant does exist..$^{42}$ For example, the recent induction of China into the World Trade Organization trading system has transformed China from 'a norm breaker to a norm taker, shaker and a maker' ${ }^{43}$ Scholars also claim that the deliberate and continued introduction and transplantation of obviously foreign legal concepts and doctrines can be motivated by local policies for innovation and creation strategy. ${ }^{44}$ However, despite the legislative efforts and enactment of the statutes in the book, the implementation of the law in practice and the law enforcement mechanisms seem to remain a concern in China. Liu, for example, paints a pessimistic picture of the legal transplant of the patent system in China. ${ }^{45}$

\section{GOVERNANCE PERSPECTIVE AND CHINESE IP LAWS}

The perplexing explanation of simultaneously successful and failed legal transplant of an IP system to Chinese soil seems to indicate that the research on Chinese IP law may need to transit from the path-dependent narratives of norm transplants to that of governance through IPR. In particular the governance thesis may explain how foreign and local doctrines and norms influence and interact with each other, after the initial phase

Development: Strategies to Optimize Economic Development in a TRIPS Plus Era (Oxford University Press 2007) 173-220.

41 See Peukert (supra, n 39). See also, A. Rahmatian, 'Neo-Colonial Aspects of Global Intellectual Property Protection' (2009) 12 Journal of World Intellectual Property 40-74.

42 For example, Yahong Li, 'Transplantation and Transformation 30 Years of Development of Chinese IP System' in Guanghua Yu (ed), The Development of the Chinese Legal System: Change and Challenges (Routledge 2011) 138-154. See also Andrea Wechsler, Intellectual Property Law in the P.R. China: A Powerful Economic Tool for Innovation and Development (12 November 2008, Max Planck Institute for Intellectual Property, Competition \& Tax Law Research Paper No. 09-02) <http://ssrn.com/abstract=1354546> accessed 31 March 2014.

43 Peter K. Yu, 'The Middle Kingdom and the Intellectual Property World' (2011) 26 Oregon Review of International Law 209-262.

$44 \mathrm{Yu}$ (supra, $\mathrm{n} 40)$ and Wechsler (supra, $\mathrm{n} 42)$.

45 Liu (supra, n 16). 
of system transplant, to emulate new norms. By framing the discussion as that of governance, the perpetual debates on the genealogy of Chinese IP law may move away from the question of the cultural and geographical origins of the IP laws to the exploration of how they are used in practice, and who and what they govern.

Governance is a concept we find in the context of a variety of social sciences, to mean any structured form of management of courses of events in a social system, or management of resources and capacities. As a perspective to study any social system, governance seems to be receiving renewed attention among researchers in the field of business studies as well as political scientists and legal scholars. ${ }^{46}$ In the context of law in general, governance perspectives highlight the institutional structure underlying a legal system, and tend to be used to understand the rule of law.

A more relevant and useful application of governance perspectives may perhaps be found in the discussions of institutional arrangements of IP law and practices - and the process - highlighting that in IP discourse, substantive norm discussions in the epistemic community itself are equally important as the process of governance that creates such norms, by the institutions and actors in the decision-making process. This is more so in an area where not only the doctrines themselves, but also the facts to which such doctrines are applied, require understanding and knowledge of persons skilled in the art. Academic debates set only in such a context would be likely to be geared inwards among the epistemic community of experts, and normative recommendations resulting from such discussions would be likely to be fed back into a self-referential autopoietic system, and thus may make its rationality immune to criticisms that are normally pitted against a social construct. As the governance perspective opens up the discourse and brings in the technology of government to the discussion of IP law, it highlights the process of implementation of the law as well as the institutions of implementing the law, including the market.

Building upon the governmentality perspective, ${ }^{47}$ the governance perspective may highlight that governance may be done through IPR by channelling certain decision making to the market. The governance perspective is often used in two contexts. Some commentators use it more as an economic term to highlight the fact that IPR govern use of resources. Thus the governance perspective used in this manner highlights

46 Lewis A. Kornhauser, 'Governance Structures, Legal Systems, and the Concept of Law' (2004) 79 Chicago Kent Law Review 355.

47 Mitchell Dean, Governmentality: Power and Rule in Modern Society (Sage Publications 2010). 
the role that an exclusive right of property and the institutions of IP play in the governance of common knowledge resources. ${ }^{48}$ Using this type of governance perspective, commentators often compare IPR as private exclusive rights to govern the use of resources with alternative regimes and explore whether the private property regime based on exclusivity is the most suitable or efficient means to govern innovation and knowledge resources. A variation of this approach is also noted by the commentators who compare a contractual or liability-based regime to the property rules of IP. ${ }^{49}$ A common theoretical starting point is that they use the concept that IPR govern the use of resources through the market. As a corollary, IPR allow non-state actors to participate in the governance on the use of resources through exercising their private rights through a functioning market.

In contrast, taking the governance perspective from the political sciences, there are those who use the governance perspective, focusing on the process of how the norms of IP are formed and on the institutions that are entrusted with the task of governance. ${ }^{50}$ Commonly, they start from the observation that the current property arrangement (normative set-up) is contingent as well as the nature of the rights. As the rights themselves may be contingent and thus can be recalibrated to suit particular purposes, the process is highlighted: as process is important, legitimacy of the process as well as efficiency of intervention into the normal workings of the patent market justifies the law/system/institution as well as the substance of the norm. Additionally, these commentators highlight information and

48 See, for example, Brett M. Frischmann, Michael J. Madison and Katherine J. Strandburg (eds), Governing Knowledge Commons (Oxford University Press 2014).

49 J.H. Reichman, 'Legal Hybrids Between the Patent and Copyright Paradigms' (1994) 94 Columbia Law Review, 2432-2558. See also Henry E. Smith, 'Intellectual Property as Property: Delineating Entitlements in Information' (2007) 116 Yale Law Journal 1742.

50 See, for example, Ingrid Schneider, 'Governing the Patent System in Europe: the EPO's Supranational Autonomy and its Need for a Regulatory Perspective' (2009) 36(8) Science and Public Policy 619-629; Antonina Bakardjieva Engelbrekt, 'Copyright from an Institutional Perspective: Actors, Interests, Stakes and the Logic of Participation' (2007) 4 Review of Economic Research on Copyright Issues 65; Robert P. Merges, 'Contracting into Liability Rules: Intellectual Property Rights and Collective Rights Organizations' (1996) 84 California Law Review 1293; Arti Rai, 'Engaging Facts and Policy: a Multi-institutional Approach to Patent System Reform' (2003) 103 Columbia Law Review 1035; Yoshiyuki Tamura, 'Towards the New Paradigm of Intellectual Property Law. The Law and Policy of Intellectual Property: Building a New Framework' (2008) 20 Intellectual Property Law and Policy Journal 1, 11-20. 
limited capacity institutions that are involved in the governance of IP and institutional interdependence/network formation through formation of clusters or nodes, as a result. As Burris, Drahos and Shearing have noted:

No one network, public or private, has information omniscience. The response of actors to this complexity has been to find ways to link networks to produce new structures of governance, a response that can be labeled nodal governance. These structures do not bring information omniscience to actors, but they do bring more information, and importantly, resources and technologies, which enable actors to become centers of governance. Nodes in the networked world are organizational centers in time and space from which the actions of governance flow (emphasis added). ${ }^{51}$

In other words, 'development in knowledge and powers of expertise' are closely connected to the idea of governance, highlighting that not only the state, but also other actors who have capacity and resources to collect necessary information, may participate in the governance..$^{52} \mathrm{In}$ sum, these commentators seem to share a belief that IP rights and the institution of 'epistemic communities' of experts need to be governed as well. Expertise, and inclusion of the process as against the exclusive process highlights that the institutional arrangements in IPR governance cannot ignore the fact that some IP institutions are better at collecting information, and this capacity of an institution to gather information may define the competence of the institution. This aspect of capacity for information collection should be a factor in deciding which governance institution should be given authority to decide.

Using these lines of argument, the governance perspective allows exploration of IP institutions at a peer position in terms of governing IP rights - the legislature, the judiciary the administration and the market and their interactions. Introduction of changes in one of these institutions through IP system reform would likely affect the operations of the other institutions. ${ }^{53}$ For example, introduction of a change in the collective management of copyright or resale rights in Chinese copyright law would need to consider the copyright licensing market and the art market in China. ${ }^{54}$

51 Scott Burris, Peter Drahos and Clifford Shearing, 'Nodal Governance' (2005) 30 Australian Journal of Legal Philosophy 30.

52 N. Rose and P. Miller, 'Political Power Beyond the State: Problematics of Government' (1992) British Journal of Sociology 173-205, 175.

53 Neil K. Komesar, Imperfect Alternatives: Choosing Institutions in Law, Economics, and Public Policy (University of Chicago Press 1994).

54 See Merges (supra, n 50); Nari Lee and Yang Li, 'Collective rights management in China and Europe: between market and authority', Chapter 12 in this 
Similarly, judicial reform also needs to consider the dynamic between the administration and the courts and to what extent deference may be given to administrative decision making. ${ }^{55}$ In principle, a specialized court with a centralized jurisdiction to hear IP disputes may seem an efficient instance of IP governance, by channelling complex cases to expert or specialist judges. The Chinese example of the new special IP court may be a case where this is indeed called for. ${ }^{56}$ In contrast, in Europe, such courts as the unified patent court seem to raise a concern as to governance of IPR in Europe. ${ }^{57}$

A more important change to be noted in the context of China and the governance thesis is the observation that governance occurs not only occur through political process, but also through exercise of private rights. The very fact that IP rights govern resources empowers private entities to participate in the process of governance. As IP governs use of resources, not only the institutions that have traditionally been considered a part of the political system (legislative, judicial and administrative), but also the market function as governing institutions. IPR are used as instances of governmentality allowing regulation through individuals and entrepreneurs. As noted by Montgomery, 'IP law represents the point of contact between mechanisms of domination - the coercive power of formal law, and techniques of the self: self regulation' ${ }^{58}$ National IP strategies are further instances where such contacts are further built upon the accepted rationalities and technology of governance through IP law and used as means to manage entrepreneurial activities. ${ }^{59}$

volume; Lin Zhou and Rosa Maria Ballardini, 'Art law and resale rights in Europe and China', Chapter 7 in this volume.

55 See for example, Rai (supra, n 50).

56 See Mingde Li, 'Special intellectual property courts in China', Chapter 16 in this volume.

57 Regulation (EU) 1257/2012 (2012) Implementing enhanced cooperation in the area of the creation of unitary patent protection, published OJEU L361/1-8; Regulation (EU) 1260/2012, Implementing enhanced cooperation in the area of the creation of unitary patent protection with regard to the application translation arrangement, published OJEU L361/89-92; Agreement on a Unified Patent Court, Document no. 16351/12 (11 January 2013). See also a commentary on the background of the agreement, H. Ullrich, 'Harmonizing Patent Law: The Untamable Union Patent' in M.-C. Janssens and G. Van Overwalle (eds), Harmonisation of European IP Law: From European Rules To Belgian Law And Practice (Bruylant 2012) 243-294.

58 Montgomery (supra, n 38) at 13.

59 See Zhang (supra, n 3). 


\section{CONCLUDING REMARKS}

As explored in the above, developments in IP law in China include the process of transplant rejection or modification but also the emergence of new norms out of local necessity. As other chapters in this volume show, in some areas of Chinese IP law reforms, external pressures still seem to be heavily present and visible. In other areas, however, the influences for normative changes are muted, or the initiatives for change seem to be based on indigenous local demand. ${ }^{60}$ The observation shows that China simultaneously takes the role of being an IP norm taker (or a recipient of legal transplants) as well as a norm maker. ${ }^{61}$

Recent IP law reform in China shows that China increasingly takes the role of 'norm maker' to govern local actors employing deliberate techniques and strategies to make inventors and creators 'governable' as exemplified by the national IP strategy, ${ }^{62}$ and utilizes concrete performance measurement ${ }^{63}$ in selected areas. At the same time, it is still visibly taking a passive role of 'norm taker' where some legislative experimentations seem to be ongoing. ${ }^{64}$

The governance perspective may explain why IP law norm and practice development in China is now based on a mix of local as well as foreign norms and systems. Indeed it allows us to make a comparison between how the two systems of laws function rather than looking into the origin of the IP law for the sake of creating doctrines and conceptual genealogy. At the same time, when norms and systems become more indigenous, similar problems of origin that we see in Europe may be experienced later in China as well. As more decisions are channelled to the market and self-regulation outside states, through private IP rights, the concerns

60 See Mingde Li, 'Intellectual property law revision in China: transplantation and transformation,' Chapter 4 in this volume. See also Yuying Guan, 'Orphan works in China and Europe', Chapter 6 in this volume.

61 See Niklas Bruun and Liguo Zhang, 'Legal transplant of intellectual property rights in China: norm taker or norm maker?', Chapter 3 in this volume.

62 Zhang (supra, n 3).

63 See, for example, Jiachun Wen, Yongtao Zhou and Xuezhong Zhu, 'Research on Patent Fees Subsided by Local Government in China' (2008) International Conference on Information Management, Innovation Management and Industrial Engineering (ICIII2008) Vol. 3, 269-274; Xibao Li, 'Behind the Recent Surge of Chinese Patenting: An Institutional View' (2012) 41(1) Research Policy 236-249. Compare, Brad Sherman, 'Governing Science-Patents and PublicSector Research in the United Kingdom' (1995) 26(1) IIC-International Review of Industrial Property and Copyright Law 15-40.

64 See for example, Lin and Ballardini (supra, n 54). 
for informational nodes as well as coordination may become a problem. Some decision making channels that role simply to the market and makes the market take the coordinator's role. The market may take the role of resource governor but the market-based decision-making process may be too opaque and amorphous. Governance perspectives allow us to explore not only the genealogy of norms, but also how further norms and practice evolve, and thus provide a useful analytical tool to explore what happens after the initial transplant in terms of innovation and creativity. As the transplanted system in China matures, this may be precisely what is needed for a comparative law research project. 